\title{
THE DRAFT COMMON FRAME OF REFERENCE (DCFR) - THE MOST INTERESTING DEVELOPMENT IN CONTRACT LAW SINCE THE CODE CIVIL AND THE BGB
}

\author{
Frank Emmert $\mathbf{~ E m}^{1}$ \\ Ph.D., University of Maastricht, the Netherlands, 1998. \\ John S. Grimes, Professor of Law Director, Center for International and \\ Comparative Law Project Director Egypt \\ Indiana University Robert H. McKinney School of Law, U.S.A.
}

\section{Sección Doctrina}

\section{Resumen}

El documento presenta el DCFR, el cual es el proyecto sobre el futuro Código de las obligaciones de la Unión Europea y que trabaja o funciona un poco como la UCC en Estados Unidos, es decir, como un modelo de código Comercial.

\footnotetext{
${ }^{1}$ Diploma in European Law, 1990, European University Institute, Florence, Italy. Zweites juristisches Staatsexamen (equivalent to the bar exam), 1992, Bavaria, Germany. LL.M., 1989, University of Michigan, Ann Arbor. Erstes juristisches Staatsexamen (equivalent to J.D.), 1988, University of Munich Law School, Germany.
} 
Después de una breve justificación histórica del proyecto, hay una presentación sobre lo que puede o no hacer el DCFR en la actualidad. Por último, el efecto potencial del proyecto del $\mathrm{MCR}$ al ser elegido por las partes en una transacción de compraventa internacional es explicado por medio de una situación hipotética.

\section{Palabras clave}

Compraventa internacional de mercaderías, elección de la ley aplicable, Contratos para la Compraventa internacional de mercaderías (CISG), Principios de Unidroit, Proyecto de Marco Común de Referencia, derecho privado europeo, derecho contractual europeo.

\section{Abstract}

The paper introduces the DCFR, which is essentially the draft of a future EU Code of Obligations and works a bit like the UCC in the USA, as a model commercial code. After a brief historic justification of the draft, there is a presentation of what the DCFR can and cannot do at the present time. Finally, the potential effect of the DCFR if chosen by the parties of an international sales transaction is explained via a hypothetical.

\section{Keywords}

International sale of goods, choice of law, CISG, Unidroit Principles, Draft Common Frame of Reference, European private law, European contract law. 


\section{Sumary}

I. What is the "draft common frame of reference"?

II. What the draft common frame of reference can and cannot do today

III. Application of the DCFR in contemporary commercial practice.

\section{WHAT IS THE "DRAFT COMMON FRAME OF REFERENCE"?}

After the horrors of World War II, European integration was conceived by Jean Monnet, and the great statesmen who understood and picked up his ideas, as a radically new way of securing long term peace and prosperity in Europe. Integration instead of exclusion, cooperation instead of discrimination, community instead of nationalism. In 1953, an initial six European states, including the "arch enemies" France and Germany, tied their fates together in the European Coal and Steel Community, designed to remove control over key industries for military buildup from nationalist politicians and giving it to dispassionate European bureaucrats. ${ }^{1}$ The European Economic Community and the European Atomic Energy Community followed in 1957. Since then, membership in the greatest experiment in voluntary integration of sovereign states has grown to 27 , with several more countries currently negotiating entry to the club. Among the many accomplishments of European integration is a period of peace between its Member States that is unprecedented in European history, as well as a general level of prosperity that has never been seen before in this part of the world. Although these accomplishments have recently been 
CUADERNOS DE LA MAESTRÍA EN DERECHO

cast in a less favorable light due to the economic crisis in Europe, the appeal of membership may well be greater than ever, which is evidenced, for example, by the application of Iceland in the wake of its economic meltdown. As more and more countries are coming to realize, being part of the European Union and having partners that are not only fair-weather friends but that are contractually obligated to stand together, is even more precious in times of hardship and crisis. For this reason, the doomsday sayers, who have been predicting the end of European integration as we know it, will be proven wrong once again and it is more likely than not that the EU will accelerate its integration program because of the crisis, rather than slow it down, let alone abandon it altogether.

One of the key components of European integration is the development of the "internal market" of the EU, which is defined as "an area without internal frontiers in which the free movement of goods, persons, services and capital is ensured". ${ }^{2}$ Merging the relatively small national markets of the Member States into one large European market yields numerous economic benefits. The ability to buy and sell to and from all Member States greatly increases trade and competitive pressures in the EU, resulting in vastly increased choices for consumers in combination with lower prices for higher quality goods and services. $^{3}$

The free movement of goods, services, people, companies, and capital, however, has presented and continues to present various challenges to European regulators and law makers. To give but one example, if goods can move freely from one Member State to another under the Cassis de Dijon principle that what is good enough in one Member State has to be good enough for the other Member States, ${ }^{4}$ a formidable race to the bottom could ensue. To ensure that Member States are not tempted to attract investment and jobs by 
waiving standards for product safety, environmental and workplace protection, etc., the EU has embarked on a massive program of harmonization of these rules across the Member States, essentially replacing diverging national legislation with common European rules.

Intensive trade between Member States with different legal rules and systems also creates challenges in the area of private international law. Every time a contract is made between parties in different Member States, the law governing the contract has to be determined. At least if the parties are both merchants, they have numerous choices regarding the applicable law. These choices include seller's law, buyer's law, the law of pretty much any other country, as well as certain international contract law regimes, such as the United Nations Convention on Contracts for the International Sale of Goods (CISG), ${ }^{5}$ or the infamous "lex mercatoria". And if the parties did not make a choice of law at all, or if their choice was ineffective, the applicable law has to be determined on the basis of private international law, which may in turn differ from one forum to another, potentially causing significant uncertainty and even an incentive for a race to the courthouse.

Against this background, harmonization of contract law across all Member States of the EU has long been an attractive idea. However, while the EU was explicitly given powers to pursue legal harmonization in areas such as environmental protection (Article 192 TFEU), free movement of services (Article 59 TFEU), the right to establishment for self-employed natural and legal persons (Article $50 \mathrm{TFEU}$ ), and the free movement of employed persons (Article 46 TFEU), a power to replace Member State contract laws with a common European system is not explicitly provided in the Treaties. ${ }^{7}$ Nevertheless, the European Commission, with encouragement and support 
from the European Parliament, started as early as 1974, to play with the idea of a "European Code of Obligations". 8 By 1980, a group of experts from all Member States, most of them academics, had been composed and by 1995, this group, on the basis of extensive comparative analysis of the legal systems of all Member States of the EU and the CISG and even the American Uniform Commercial Code (UCC), had completed the first phase of its work: "The Principles of European Contract Law (PECL), Part I, Performance, Non Performance and Remedies.”(Lando \& Beale, 2000, p. xi)

As the name suggests, these "Principles" were no code at all, certainly not in the form of binding legislation. They were, however, formulated in such a way that they could be adopted as legislation, much like the well known model codes in the American system, with the UCC just the best known example. And although not a single country has as yet adopted the Principles as domestic law, and they remain, therefore, really just a good idea, these European Principles quickly became immensely popular among comparativists and private international lawyers. This popularity is based on two grounds. First, the team around Professor Ole Lando had accomplished a genuine synthesis of all European contract laws, to the extent that they found broad support in every single Member State. Second, and even more importantly, the Principles are crafted in elegant, simple, and efficient language, much easier to understand than any other contract law around the world.

This explains why the Lando Group continued, and in 1999 presented the second phase of its work, this time covering rules on formation of contracts, authority of agents to bind their principal, validity of contracts, interpretation, content, and effects. ${ }^{9}$ A third part followed in $2003 .{ }^{10}$ It also explains why 
CUADERNOS DE LA MAESTRÍA EN DERECHO

other groups have become busy ${ }^{11}$ and have been working, with the same or similar methods, ${ }^{12}$ in other areas of civil law. After broad consultations with Member State governments, enterprises, legal professionals, consumer organizations, and other stakeholders, the EU Commission, in its 2003 Action Plan for European Contract Law, ${ }^{13}$ announced the concept of a Common Frame of Reference (CFR), envisioned as a collection of the "best solutions" for definitions, terminology, and substantive rules in European private law. To this end, the various academic groups were brought together, the pre-existing Principles were united, and the remaining gaps were filled. Although the Commission and the academic study groups nowadays avoid the politically sensitive language of a "European Civil Code", the 2009 Draft Common Frame of Reference, as the preliminary end result of the comparative study and drafting process, retains the format of a model code and, fortunately, also retains the elegance, efficiency, and comprehensibility that were the hallmark of the original European Principles. ${ }^{14}$

The DCFR is organized by "books" in the following manner:

- Book I covers "General Provisions", such as the "intended field of application", the principle of "good faith and fair dealing", and rules about "computation of time".

- Book II covers "Contracts and Other Juridical Acts" in a general manner, with chapters on "general provisions", "non-discrimination", "marketing and pre-contractual duties", "formation", "right of withdrawal", "representation", "grounds of invalidity", "interpretation", as well as "contents and effects of contracts". 
- Book III covers "Obligations and Corresponding Rights", in particular "performance", "remedies for non-performance", problems related to "plurality of debtors and creditors", "change of parties", "set-off and merger" of contracts, and "prescription".

- Book IV, in many ways the heart of the code, covers "Specific Contracts and the Rights and Obligations Arising from Them", with chapters on "sales", "lease of goods", "services", "mandate contracts", 15 "commercial agency, franchise and distributorship", "loan contracts", "personal security", and "donation" agreements.

- Book V deals with "Benevolent Intervention in Another's Affairs".

- Book VI covers "Non-Contractual Liability Arising out of Damage Caused to Another", i.e. tort law.

- Book VII deals with "Unjust Enrichment".

- Book VIII is about "Acquisition and Loss of Ownership of Goods".

- Book IX covers "Proprietary Security in Movable Assets".

- Book X is about "Trusts".

- Finally, there is an extensive annex with definitions and an index, bringing the entire document to a good $600+$ pages.

As can been seen even from this extremely brief introduction, considerable time and money has been expended for the development of this Draft and this begs the question: What is the point, what is the purpose, beyond mere academic curiosity, what is the usefulness of the Draft Common Frame of Reference? This shall now be addressed in the second part of the article. 


\section{WHAT THE DRAFT COMMON FRAME OF REFERENCE CAN AND CANNOT DO TODAY}

The declared purposes of the DCFR are actually quite modest. First, and consistent with the mandate given to the drafters by the EU Commission, the DCFR is "a possible model for a political CFR" (Von Bar, Clive \& Schulte-Nölk, 2009, para.6 p.7) a proposal for what could eventually evolve into a European Code of Obligations. Along this path, the DCFR is more likely to be used as a quarry, from which precious stones are mined to be used in other constructs, ${ }^{16}$ although it could just as well form a blueprint to be adopted, lock stock and barrel, as binding European legislation ${ }^{17}$.

The second purpose is for "legal science, research and education" (Von Bar, Clive \& Schulte-Nölk, 2009, para.7 p.7), to show to students, reseachers and professors the vast areas of private law that are indeed very similar across Europe, or at least typically lead to similar, if not identical, outcomes, and "the relatively small number of cases in which the different legal systems produce substantially different answers to common problems."( Von Bar, Clive \& Schulte-Nölk, 2009, para.7 p.7). Indeed, when I was Dean of an international law school in the Baltics in the early 2000s, where we delivered a law program in English to students from a number of different countries, I taught Contract Law on the basis of the PECL instead of any one of the national contracts laws, which were still in flux in the early years of transition from Communism, and in any case where not available in English or any one other language accessible to all of our students. What surprised me most about this experiment was how easy it was to communicate not only the basics but also the intricacies of this field of law on the basis of the PECL. With my German background, I had previously thought of the German Bürgerliches Gesetzbuch 
$(B G B)$ as the pinnacle of wisdom and had greatly enjoyed my studies under giants like Dieter Medicus in Munich. While I had already heard that the Dutch Wetbook was a much more modern and easier code than the BGB and the French Code Civil, it is one thing to hear such claims and quite another to experience that, indeed, there could be such a thing as legislation more logical and systematic and ultimately more accessible than German legislation.

The third declared purpose of the DCFR is to provide "a possible source of inspiration" (Von Bar, Clive \& Schulte-Nölk, 2009, para.8 p.7-9) for legislative drafters. This is different from the first purpose because it is aimed primarily at the Member State level, as well as any other countries around the world, where efforts are undertaken at modernization of contract law, independent from the motive of harmonization in the EU internal market.

The purpose of inspiring lawyers to pursue a "modernization" of their respective contract laws does not have to be limited to legislative drafting projects, however. The freedom of contract, at least for commercial agreements between merchants, is virtually unlimited. It not only allows merchants to design their substantive contract terms any way they see fit. It also extends to the choice of law and forum for the settlement of any disputes. And, as already stated above, the choices for the applicable law and forum are many, including some that make sense and some that don't. Among the considerations that should go into a well drafted contract are the following:

1) The applicable law has to be predictable. This requires an explicit and effective choice of law. Avoiding a choice altogether or trying to make a choice that turns out to be ineffective, creates unnecessary problems in case of a dispute over correct performance of the contractual obligations. Even before substantive issues 
can be addressed, the parties may have to spend time and money fighting over the applicable law as a preliminary question. Depending on where such a fight may be taken, the court (= forum) will apply its own private international law to determine the applicable substantive law. And this can be unpredictable. Some countries simply refer to seller's law as the applicable law. Others refer to the law of the country with the closest connection to the contract. This, in turn, may be seller's law if it is defined as the country where the party that has to effect the characteristic performance is domiciled. However, it can also be a reference to the place where the characteristic performance has to be effected, which in turn can depend on the chosen Incoterm.

2) The choice of law and forum also has to be efficient. This may require considerations about speediness of a particular venue, travel and translation expenses, other costs and their distribution between the parties, and the enforceability of the decision(s) of the dispute settlement body.

3) Finally, the choice of law and forum has to be fair. Unfortunately, the lawyers like to forget that for their clients it is often more important to continue a business relationship than to win a particular dispute. A settlement on reasonable terms may be more advantageous in the long term than the extraction of maximum benefits in the short term.

With regard to consumer contracts, most national legal systems provide safeguards to assure that the professional party cannot take advantage of the lack of experience and specialized knowledge of the private party. For business-to-business contracts, by contrast, no such safeguards are provided since it is assumed that merchants know what they are doing. In practice, however, this is by no means always the case and the majority of agreements for the sale of goods, let alone agreements for more complex business dealings, are drafted by in-house lawyers or 
external attorneys. And this is where the DCFR could and should come in, as inspiration to the lawyers drafting the international sales agreements and - ideally as the chosen legal system for such agreements. In spite of many obvious advantages, however, our lawyers are rarely inspired and generally opt for their own legal system as the applicable law. Unfortunately, they do this primarily in their own best interest - because that happens to be the legal system they know best and often the only legal system they know at all - and not necessarily in their client's best interest. This will be illustrated in Part III with an example.

\section{APPLICATION OF THE DCFR IN CONTEMPORARY COMMERCIAL PRACTICE}

In our hypothetical, Botellas PET SA in Bogotà wants to buy a new injection molding machine for the production of plastic bottles for non-alcoholic carbonated beverages. B has identified Shure Robotics Inc in Indianapolis as the manufacturer offering the fastest machines at the lowest prices. According to S's website, their model TX1500 can make 30 bottles per cycle and 50 cycles per hour, adding up to 1'500 bottles every hour. The purchase price of the machine is USD 2.4 million EXW, which makes it the largest single acquisition in the history of B. Therefore, they need to make absolutely sure that all required elements of the documentary sale are carefully drafted to ensure smooth implementation of this important transaction.

The typical documentary sale consist of four separate contracts, all of which have to be drafted and negotiated between the parties. The most important is the contract for the sale of the machine. In addition, there will be a financing contract for the payment of the purchase price, typically in the form of a letter of credit. Then there will be a shipping contract, typically in the form of a bill of lading. Finally, the 
party or parties bearing the risk of loss or damage during transport will enter into an insurance contract. The second, third and fourth are usually pre-formulated by the bank, shipping and insurance company respectively. Nevertheless, the merchants have to make certain choices in them and have to do so in a way that is both fair and efficient. ${ }^{18}$ The contract for the sale of the goods, by contrast, is in no way pre-determined and can be anything from a very superficial oral agreement to a very sophisticated document of 50-100 pages.

Although all elements of the contract of sale can usually be written down in clear and unambiguous language on about 6-10 pages, the average law firm, certainly in the United States, typically comes up with a multiple of this. They will claim that their lengthy elaborations are necessary to cover all eventualities and yet, they accomplish often the exact opposite. The large majority of these contracts are copy-pasted patchwork from previously drafted agreements that have been sitting on computer hard-drives at the firm. As a consequence, verbose language and generally poor drafting, including ambiguous language and even mutually contradictory terms in different parts of a contract, are perpetuated. Individual provisions are not individually thought through and may indeed be bad for the client. One example is the choice of law and forum. Few and far between are the attorneys that will even consider a choice of law other than their own or a forum outside of their own bailiwick. After all, if a dispute should arise, the attorneys would not get to handle it if they are not familiar with the applicable law and/or are not admitted to the bar in the country where the court will be hearing the case.

In our hypothetical, if the seller $\mathrm{S}$ is providing the first draft of the sales agreement, chances are that her lawyers will choose the law of Indiana as the applicable law and the courts of Indiana as the chosen forum. Under no circumstances will they consent to buyer's law (Columbia) and buyer's courts. If the 
buyer refuses to litigate in US courts, seller will probably accept to go to arbitration but will probably continue to insist on the application of the UCC. Let's consider the consequences of such a choice of law and forum. The most common problems of performance are a) buyer does not pay, and b) seller's machine does not perform. If there should be a problem for the seller to get paid, she would be very poorly served if she now had to go to court in Indiana. While application of Indiana law or UCC would not be a problem, a judgment from a U.S. court will not easily be enforceable in Columbia, where buyer's assets are located. This would already be quite different if the parties had agreed to arbitration because Columbia is a signatory to the New York Convention on the Recognition and Enforcement of Foreign Arbitral Awards. Pursuant to Article III et seq. of that Convention, Columbian courts will enforce an international arbitral award without further complications. However, the arbitration may have cost the parties quite a lot of money and there is normally no fee shifting, meaning that the fees are divided regardless of who wins and who loses.

The issue gets even more interesting if there is a problem with seller's performance, i.e. if the machine does not produce 1'500 bottles per hour. If the seller insisted on application of the UCC, she will be bound by the so-called "perfect tender" rule in $\$ 2-601$. This would entitle the buyer to reject the entire performance if "the goods or the tender fail in any respect to conform to the contract" (emphasis added). In practice, an injection molding machine will require several days for installation, potentially up to several weeks of running-in and training, and only then it will become apparent whether or not the machine is capable of producing the contractually promised number of units. Let's assume the machine, after the required preparations, simply does not get up to the promised 1,500 bottles. On a good day, it may come close, say 1'400 or even 1'450, but on a bad day it barely 
produces 1'300 bottles in an hour. My clients in the industry assure me that this is a fairly common type of issue with these kind of machines.

Under the perfect tender rule of the UCC, as originally conceived and phrased, a buyer could potentially reject the seller's performance if the machines fell short by even just a single bottle. Fortunately, no court in the U.S., let alone the rest of the world, today applies a strictly literal interpretation of the perfect tender rule. However, once a performance of the type here in question falls short, on average, by more than $5-10 \%$, the UCC kicks in and the buyer can indeed reject the performance. What this means in practice can be nicely illustrated by our case. Once the buyer reject's the seller's performance, the seller has just two choices: she can send another machine to Columbia in the hope that it will do better and that the buyer will eventually have to pay the contracted price, minus damages for delay, lost profit, etc. Or she can give up on the transaction, waive her claim to the contracted price and refund any money that has already been paid, plus any damages for delay, lost profit, etc. In both cases, the imperfect machine sitting in Colombia has probably become a very expensive piece of scrap metal, much more of a liability for the seller than an asset. $^{19}$

The situation for the seller changes dramatically if the contract is not subject to the UCC but to any of the laws in the continental European tradition. These legal systems do not have a similarly strict standard for the performance of the seller. Instead, they usually apply the test whether there was a "fundamental breach" of the contractual obligations, which means that the buyer can only reject the performance of the seller if there is a "fundamental breach". In the practice of the courts, a fundamental breach is found either if the performance objectively deviates so significantly from what had been promised and expected that a mere compensation for damages is inadequate. A deviation of 5 or $10 \%$ from the expected performance 
CUADERNOS DE LA MAESTRÍA EN DERECHO

will normally not fulfill this test. A stricter standard is applied only if the seller knew that strict compliance with the contractual promises was of essential importance to the buyer. In our hypothetical, this would only be the case if the buyer had clearly communicated that an output of 1'500 bottles per hour was the very reason for choosing this machine and that anything less would be basically useless to the buyer.

As a consequence, if Dutch, French, German, or Swiss law, to name just a few, would be applied to the contract in our example, the buyer would not be entitled to reject the performance altogether. Instead, the buyer would have to keep the machine and pay for it, however, with a set-off equivalent to damages for the lower output.

Of course, a choice of a particular national European legal system would be inefficient for the parties in the example. Neither of them probably knows much about these legal systems and in most likelihood, neither speaks the respective language (well enough). Furthermore, the chosen forum has to be considered. State courts, whether in Indiana or anywhere else, should never be made to apply a foreign law. They would ask for extensive expert opinions and translations, which creates unnecessary costs. Arbitrators, of course, can be selected to have any required expertise, but they may be more expensive if they are not from the country or region where the dispute has to be settled. Much better, therefore, would be the choice of one of the international contract regimes. The best known and most widely used is the CISG. In fact, this regime would become the applicable law of its own motion in a contract between an American and a Colombian party on the basis of its Article 1(1)(a), unless it is specifically excluded. However, if the parties are making a conscious choice of an international contract law regime, the CISG is not necessarily the best choice they can make. For the most part, the provisions of the CISG, the Unidroit Principles, and the DCFR should lead to the same result, certainly with 
regard to the problem in our hypothetical. That being said, there are differences in detail between the three regimes. First, there is the question whether the regime is well known to whichever forum is selected by the parties. The CISG has the advantage here and the DCFR is probably the least well known, although it is catching up. Second, there is the question of comprehensiveness. All three regimes do not cover every possible question and need to be accompanied with a backup choice of law, for example "the contract shall be governed by the CISG; for any questions not covered therein, Swiss law shall apply". ${ }^{20}$ In this respect, the advantage is with the DCFR, which is the most comprehensive and leaves the fewest questions unresolved. Finally, the third question is about comprehensibility and efficiency. Once again, the DCFR has the advantage here. Even a superficial reading of the three texts shows right away that the DCFR is more easily understandable, better organized, and generally more clear and straightforward than the other two.

In concluding, I would advise the American seller to make a choice for the DCFR and arbitration. ${ }^{21}$ As for the Colombian buyer, the best choices would probably be for the UCC with litigation in Indiana. Although the latter would be expensive, Indiana courts would happily apply the prefect tender rule and any decisions could be easily enforced against the American seller. Ironically, UCC and Indiana courts are most likely also the recommendation of the attorneys retained by Shure Robotics at considerable expense. 


\section{Bibliography}

ANTONIOLLI, L. \& FIORENTINI, F. (2011). A Factual Assessment of the Draft Common Frame of Reference. (pp. 3-7 and 419 et seq). Munich: Sellier.

ARTIS, M. \& NIXSON, F. (Eds., 2007). The Economics of the European UnionPolicy Analysis (4. ${ }^{\text {th }}$ ed.). Oxford: Oxford University Press.

BEALE, H., HARTKAMP, A., KÖTZ, H. \& TALLON, D. (Eds., 2002). Cases, Materials and Text on Contract Law. Oxford: Hart Publishing.

BEATSON, J. \& SCHRAGE, E. (Eds., 2003). Cases, Materials and Texts on Unjustified Enrichment. Oxford: Hart Publishing.

CHOW, D. (2010). International Business Transactions. (2.nd ed.). New York: Wolters Kluwer Law \& Business.

DINAN, D. (2004). Europe Recast - a History of European Union. Basingstoke: Palgrave Macmillan.

EJC C- 120/78, Rewe-Zentral AG v Bundesmonopolverwaltung für Branntwein. ECR 20 February 1979 649. (Rec. 14)

EU Commission (Ed.). Action Plan on a More Coherent European Contract Law, 12 February 2003, COM/2003/68 fin.

FERRARI, F. (2011). Contracts for the International Sale of Goods - Applicability and Applications of the 1980 United Nations Sales Convention. The Hague: Martinus Nijhoff.

HANSEN, J. D. (2001). European Integration - an Economic Perspective. Oxford: Oxford University Press. 
CUADERNOS DE LA MAESTRÍA EN DERECHO

HUBER, P. \& MULLIS, A. (2007). The CISG - a New Textbook for Students and Practitioners. München: Sellier.

International Institute for the Unification of Private Law. Unidroit Principles of International Commercial Contracts. Retrieved March 21, 2012, from http://www.unidroit.org/english/principles/contracts/main.htm.

KRÖLL, S., MISTELIS, L. \& PERALES, P. (Eds., 2011). UN Convention on Contracts for the International Sale of Goods (CISG) - Commentary. München: Verlag C. H. Beck.

LANDO, O., CLIVE, E., Prüm, A. \& ZIMMERMANN, R. (Eds., 2003). Principles of European Contract Law Part III, The Hague: Kluwer Law International.

LANDO, O. \& BEALE, H. (Eds., 2000), Principles of European Contract Law (p. xi). The Hague: Kluwer Law International.

LANDO, O. \& BEALE, H. (Eds., 1999). Principles of European Contract Law, Parts I and II. The Hague: Kluwer Law International.

LOOKOFSKY, J. (2008). Understanding the CISG in the USA (3. ${ }^{\text {rd }}$ ed.). The Hague: Kluwer Law International.

MCDONALD, F. \& DEARDEN, S. (2005). European Economic Integration (4. ${ }^{\text {th }}$ ed.). Harlow: Financial Times/Prentice Hall.

MICKLITZ, H., STUYCK, J. \& TERRYN, E. (Eds., 2010). Cases, Materials and Text on Consumer Law. Oxford: Hart Publishing.

MOENS, G. \& GILLIES, P.(2006). International Trade \& Business - Law, Policy and Ethics. Oxford: Routledge/Cavendish

MOLLE, W. (2006). The Economics of European Integration - Theory, Practice, Policy $\left(5^{\text {th }}\right.$ ed.). Aldershot: Ashgate. 
NEAL, L. \& BARBEZAT, D. (1998). The Economics of the European Union and the Economics of Europe. Oxford: Oxford University Press.

PELKMANS, J. (2006). European Integration - Methods and Economic Analysis (3. ${ }^{\text {rd }}$ ed.). Harlow: Prentice Hall/Financial Times.

SCHIEK, D., Waddington, L. \& BELL, M. (Eds., 2007). Cases, Materials and Text on National, Supranational and International Non-Discrimination Law. Oxford: Hart Publishing.

SCHLECHTRIEM, P. \& SCHWENZER, I. (Eds., 2010). Commentary on the UN Convention on the International Sale of Goods-CISG (3. ${ }^{\text {rd }}$ ed.). Oxford: Oxford University Press.

The free dictionary by farlex. Retrieved March 21, 2012, from http://legal-dictionary.thefreedictionary.com/Lex+mercatoria.

Treaty on the Functioning of the European Union TFEU. Article 26 (2).

Van Gerven, W.(2001). Tort Law. Oxford: Hart Publishing.

VOGENAUER, S. \& KLEINHEISTERKAMP, J. (2009). Commentary on the Unidroit Principles of International Commercial Contracts (PICC). Oxford: Oxford University Press.

VON BAR, C., CLIVE, E. \& SCHULTE-NÖLK, H.(Eds., 2009). Principles, Definitions and Model Rules of European Private Law - Draft Common Frame of Reference (DCFR)- Outline Edition (p.7-9). Munich: Sieller. Retrieved March 21, 2012, available at:

https://www.law.kuleuven.be/web/mstorme/2009_02_DCFR_OutlineEdition.pdf 


\section{Footnotes}

CUADERNOS DE LA MAESTRÍA EN DERECHO

${ }^{1}$ For more information see, for example, Dinan, D. (2004). Europe Recast - a History of European Union. Basingstoke: Palgrave Macmillan.

2 See Article 26(2), formerly Article 14(2), of the Treaty on the Functioning of the European Union TFEU.

${ }^{3}$ Good books on the subject include: Artis, M. \& Nixson, F. (Eds., 2007). The Economics of the European Union - Policy Analysis (4. ${ }^{\text {th }}$ ed.). Oxford: Oxford University Press; Jørgen Drud Hansen, J. D. (2001). European Integration - an Economic Perspective. Oxford: Oxford University Press; McDonald, F. \& Dearden, S. (2005). European Economic Integration (4. ${ }^{\text {th }}$ ed.). Harlow: Financial Times/Prentice Hall; Molle, W. (2006). The Economics of European Integration - Theory, Practice, Policy (5 ${ }^{\text {th }}$ ed.). Aldershot: Ashgate ; Neal, L. \& Barbezat, D. (1998). The Economics of the European Union and the Economics of Europe. Oxford: Oxford University Press; and in particular Pelkmans, J. (2006). European Integration - Methods and Economic Analysis (3. ${ }^{\text {rd }}$ ed.). Harlow: Prentice Hall/Financial Times.

${ }^{4}$ See the Judgment of the European Court of Justice of 20 February 1979 in Rewe-Zentral AG v Bundesmonopolverwaltung für Branntwein, 1979 ECR 649, in particular Rec. 14.

5 The literature on the CISG is vast. An easy introduction is supplied by: Ferrari, F. (2011). Contracts for the International Sale of Goods - Applicability and Applications of the 1980 United Nations Sales Convention. The Hague: Martinus Nijhoff; see also Huber, P. \& Mullis, A. (2007). The CISG - a New Textbookfor Students and Practitioners. München: Sellier; and Lookofsky, J. (2008). Understanding the CISG in the USA (3. ${ }^{\text {rd }}$ ed.). The Hague: Wolters Kluwer Law International. For comprehensive analysis, see Kröll, S., Mistelis, L. \& Perales, P. (Eds., 2011). 
CUADERNOS DE LA MAESTRÍA EN DERECHO

UN Convention on Contracts for the International Sale of Goods (CISG) - Commentary. München: Verlag C. H. Beck; and, in particular, Schlechtriem, P. \& Schwenzer, I. (Eds., 2010). Commentary on the UN Convention on the International Sale of Goods-CISG (3. ${ }^{\text {rd }}$ ed.). Oxford: Oxford University Press.

${ }^{6}$ Literally translated, "lex mercatoria" means "law of merchants". Commonly, the reference is to the customs and unwritten rules applied within a certain circle of traders. Essentially, these were self-enforced: if you didn't play by the rules, your former business partners would shun you and/or you could not get deals or credit on the same good terms (any more). On the one hand, the "lex mercatoria" could differ from one trade or industry to another, on the other hand, it was never written down, let alone adopted as law, in any coherent and systematic fashion. Entirely wrong is, therefore, the definition provided by "The Free Dictionary by Farlex", which says that LEX MERCATORIA is "[t]hat system of laws which is adopted by all commercial nations, and which, therefore, constitutes a part of the law of the land." (see http://legal-dictionary.thefreedictionary.com/Lex+mercatoria). Fortunately, the core of the lex mercatoria was eventually codified and is now available to us in multiple languages in the form of the Unidroit Principles of International Commercial Contracts adopted by the International Institute for the Unifcation of Private Law UNIDROIT in Rome in 2004, available online at http://www.unidroit.org/english/principles/contracts/main.htm. Even these, however, are not part of the law of the land anywhere in the world and only become applicable if merchants agree to use them as (part of) the law to govern their contract by explicit reference to the Unidroit Prinples or the lex mercatoria. For comprehensive analysis of the UNIDROIT Principles see: Vogenauer, S. \& 
Kleinheisterkamp, J. (Eds., 2009). Commentary on the Unidroit Principles of International Commercial Contracts (PICC). Oxford: Oxford University Press.

7 To retain their sovereignty, the Member States have clearly established the principle of enumerated powers codified in Article 5 TEU: “(1) The limits of Union competences are governed by the principle of conferral.... (2) Under the principle of conferral, the Union shall act only within the limits of the competences conferred upon it by the Member States in the Treaties .... Competences not conferred upon the Union in the Treaties remain with the Member States."

${ }^{8}$ Ole Lando tells the story "How It Started" in the Preface Lando, O. \& Beale, H. (Eds., 2000), Principles of European Contract Law (p. xi). The Hague: Wolters Kluwer Law International.

${ }^{9}$ Lando, O. \& Beale, H. (Eds., 1999). Principles of European Contract Law, Parts I and II. The Hague: Wolters Kluwer Law International.

${ }^{10}$ Lando, O., Clive, E., Prüm, A. \& Zimmermann, R. (Eds., 2003). Principles of European Contract Law Part II. The Hague: Wolters Kluwer Law International. This third part covers plurality of parties, assignment of claims, substitution of new debtor: transfer of contract, set-off, prescription, illegality, conditions, and capitalization of interest.

${ }^{11}$ To name just a few, the Lando Commission was succeeded by the Study Group on a European Civil Code in 1998 and from 1992 to 2005, the European Group on Tort Law produced the Principles of European Tort Law (PETL). For much more detail on these initiatives and a comprehensive bibliography see: Antoniolli, L. \& Fiorentini, F. (2011). A Factual Assessment of the Draft Common Frame of Reference. (pp. 3-7 and 419 et seq). Munich: Sellier. 
CUADERNOS DE LA MAESTRÍA EN DERECHO

12 An interesting approach was also pioneered by former Advocate General Walter van Gerven with the Ius Commune Casebook series. The editors collect national court judgments from across the Member States of the EU and show that comparable fact scenarios result in comparable judicial decisions, which in turn proves the common core or common heritage of law in Europe. For examples in the Ius Commune Casebooks for the Common Law of Europe series by Hart Publishing see: Beale, H., Hartkamp, A., Kötz, H. \& Tallon, D. (Eds., 2002). Cases, Materials and Text on Contract Law. Oxford: Hart Publishing; Beatson, J. \& Schrage, E. (Eds., 2003). Cases, Materials and Texts on Unjustified Enrichment. Oxford: Hart Publishing; Micklitz, H., Stuyck, J. \& Terryn, E. (Eds., 2010). Cases, Materials and Text on Consumer Law. Oxford: Hart Publishing ; Schiek, D., Waddington, L. \& Bell, M. (Eds., 2007). Cases, Materials and Text on National, Supranational and International Non-Discrimination Law. Oxford: Hart Publishing; and Van Gerven, W.(2001). Tort Law. Oxford: Hart Publishing.

${ }^{13}$ EU Commission (Ed.). Action Plan on a More Coherent European Contract Law, 12 February 2003, COM/2003/68 fin.

14 The full text of the Outline Edition of the Principles, Definitions and Model Rules of European Private Law - Draft Common Frame of Reference (DCFR) can be downloaded for free at https://www.law.kuleuven.be/web/mstorme/2009_02_DCFR_OutlineEdition.pdf (Von Bar, Clive, \& Schulte-Nölk, 2009).

15 These are essentially personal agency contracts. 
CUADERNOS DE LA MAESTRÍA EN DERECHO

16 The Outline Edition of the DCFR itself refers to a European directive on consumer contractual rights as an example, see paras. 59 et seq., in particular para. 62, of the Introduction (on p. 37) (Von Bar, Clive, \& Schulte-Nölk, 2009).

${ }^{17}$ Cf. According to the European Commission (2011). Proposal for a Regulation Of The European Parliament And Of The Council on a Common European Sales Law, 635 final, Brussels 11 October 2011, from: http://eur-lex.europa.eu/LexUriServ/LexUriServ.do?uri=COM:2011:0635:FIN:EN:PDF, 27.3.2012.

${ }^{18}$ It would go beyond the scope of the present article to try to outline even just the most important elements and the most common mistakes in all of these agreements. It usually takes me anywhere from a couple of weeks to an entire semester to teach all of these. While my own textbook on International Business Transactions is still being written, I recommend Chow, D. (2010). International Business Transactions. (2. ${ }^{\text {nd }}$ ed.). New York: Wolters Kluwer Law \& Business; and Moens, G. \& Gillies, P.(2006). International Trade \& Business - Law, Policy and Ethics. Oxford: Routledge/Cavendish.

19 The perfect tender rule is by no means the only problem with the application of the UCC to international commercial contracts. Several other important rules differ from the standards used in most other countries and do so often to the disadvantage of (American) exporters.

${ }^{20}$ Anything else would be an incomplete choice of law and would require, in case such a problem did arise, that the backup is determined by the forum on the basis of its private international law.

${ }^{21}$ I would not advise any party at this time to bring the DCFR to a regular court, since the outcome is still too unpredictable, given the limited experience of most courts with this regime. 